\title{
Current Status - Hydrogeology in Nova Scotia*
}

\author{
J. F. JONES \\ Groundwater Section, Nova Scotia Department of Mines, Halifax, N.S.
}

This report includes information on the current hydrogeological program, conducted by the Groundwater Section, Nova Scotia Department of Mines.

These programs can be divided into three major categories:

1) immediate action requests to provide groundwater supplies for individuals, municipalities, and industries;

2) long term field research and laboratory studies to evaluate the Province's groundwater resources; and

3) basic data collection and compilation, educational programs, and administration of the Well Drilling Act.

Emphasis in this report will be mainly on the research aspects of the program.

\section{(1) Action Requests}

The Groundwater Section continues to as ist individuals, municipalities, industries, federal and provincial government agencies to obtain water supplies from areas favourable for groundwater development.

Some recent projects include: (1) assistance to the Town of Digby during a water supply shortage to obtain supplement water from wells drilled into Triassic sandstone beds. This aquifer can be developed by proper well construction to produce individual well yields up to 300 imperial gallons per minute $(432,000$ gallons per day);

(2) A test drilling in the immediate vicinity of Truro which has revealed that large-capacity screened wells yielding in the order of one to two million imperial gallons per day can be constructed in near surface glacio-fluvial sand and gravel deposits. Additional large capacity wells (300 to 400 imperial gallons per minute) can be easily developed in the underlying Triassic bedrock aquifers. This area has considerable potential for large-scale groundwater development;

(3) Evaluation of the groundwater potential for the Town of Pictou for future development of groundwater sources from glacio-fluvial sand and gravel deposits and underlying aquifers of Pennsylvanian age (Riversdale and Pictou Groups);

(4) Assistance to the Town of Antigonish in evaluating a groundwater supply from sands and gravels in an alluvial terrace adjacent to the Rights $R$ iver in the immediate vicinity of the Town.

In addition to the above, many letter type reports have been written, and short investigations carried out in response to individual inquiries.

\section{(2) Research and General Field Programs}

Field programs were carried out during the past summer in three areas of the Province: the Musquodoboit River Valley, the Salmon River watershed near Truro, and Windsor and Digby, at the two extremities of the Annapolis-Cornwallis Valley. These programs are jointly sponsored by the Province and ARDA.

Chang Lu Lin, a graduate student working towards his Ph. D. at the Univer sity of Illinois, carried out a field program in the Musquodoboit River Valley. His particular field of study is the unconfined flow of groundwater in near surface aquifers, and the changes in groundwater chemistry between aquifers of markedly contrasting permeabilities, i. e. till versus glacio-fluvial sands and gravels.

George F. Pinder is working on another important objective in groundwater hydrology, the prediction of the distribution of $\mathrm{drawdown}$ in a groundwater reservoir after a specified period of pumping. In order to make such a prediction it is necessary to determine the hydrologic and geologic characteristics of the reservoir and to incorporate this information into a model. This model must be adjusted until historical records are reproduced; it is then pumped for a specified period and the response of the reservoir measured.

Preliminary investigations at Musquodoboit Harbour, Nova Scotia (Pinder, 1967) indicated

*Manuscript received November 28, 1968. 
that a model of glacial-fluvial deposits at this location would aid in the evaluation of the water resource potential of the area. The complex boundary conditions of the reservoir made the construction of an electric analogue model difficult and a digital model was developed. This model consisted of a computer program for the solution of the flow equations for a non-homogeneous, confined aquifer with irregular boundary conditions (Fig. 1). This program is now being employed, in conjunction with field investigations as previously mentioned, in a study of the effect of well spacing and pumping rates on an aquifer at Antigonish, Nova Scotia.

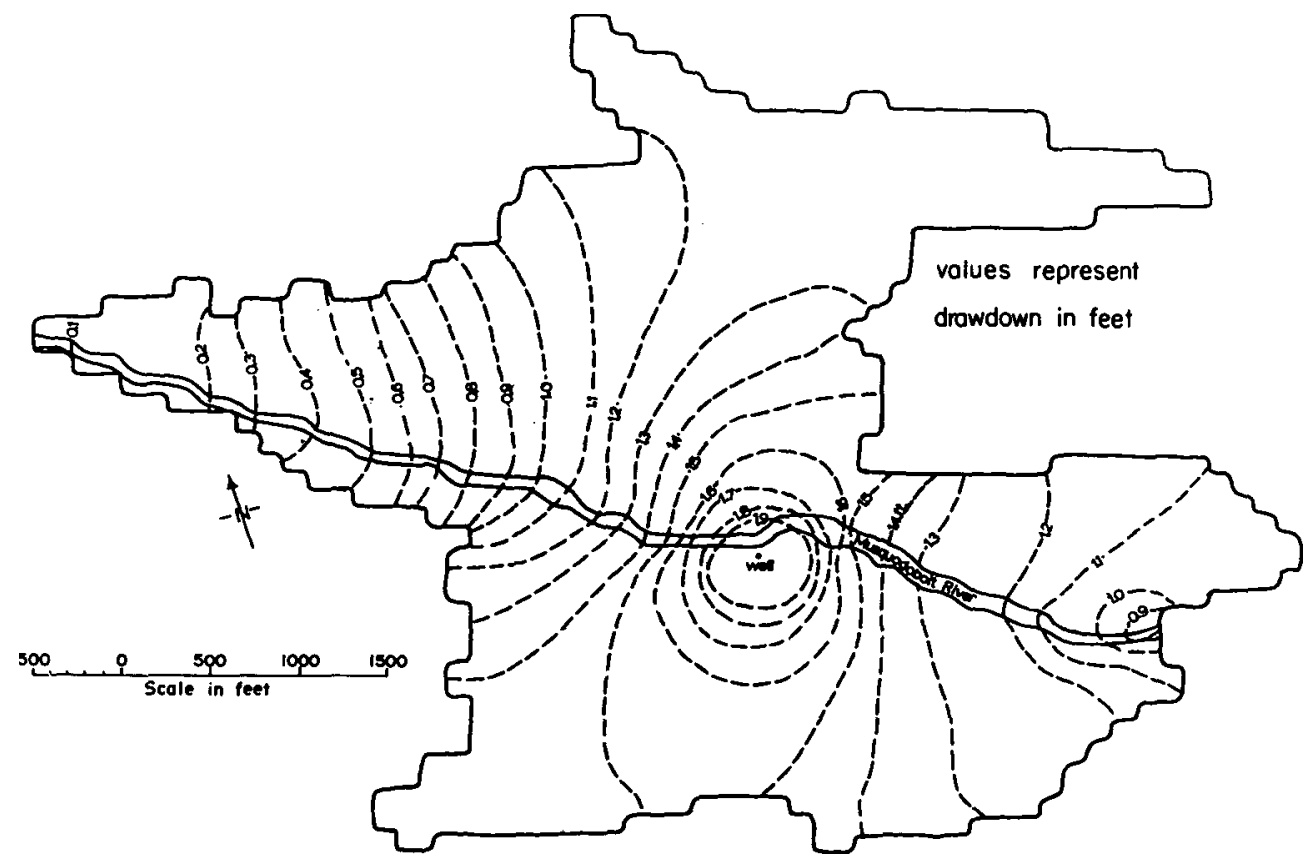

Figure 1 Piezometric surface determined from the digital model after 206.65 days of pumping at a rate of $0.963 \mathrm{cfs}$. (after Bredehoeft and Pinder, 1968)

The determination of the groundwater component of streamflow during flood stage is another important objective in both groundwater and surface water investigations. Arbitrary graphical separation of streamflow hydrographs into their various components is presently the most popular approach to solving this problem.

Recent investigations of the streamflow chemistry at three Nova Scotia International Hydrologic Decade basins indicate that a quantitative determination of groundwater discharge during peak flow can be obtained using the solute concentration of total runoff. A chemical mass balance was employed to develop the expression:

where:

$$
Q_{\mathrm{gw}}=\left[\left(C_{\mathrm{tr}}-C_{\mathrm{dr}}\right) /\left(\mathrm{C}_{\mathrm{gw}}-\mathrm{C}_{\mathrm{dr}}\right)\right] \Omega_{\mathrm{tr}}
$$

$\mathrm{C}_{\mathrm{tr}}$ is the total dissolved solids concentration in total runoff (ppm)

$\mathrm{C} d r$ is the total dissolved solids concentration in direct runoff (ppm)

$\mathrm{C}_{\mathrm{gw}}$ is the total dissolved solids concentration in groundwater runoff (ppm)

$Q_{\text {tr }}$ is the total runoff (cfs)

$Q_{\mathrm{dr}}$ is the direct runoff (cfs)

$\mathrm{Q}_{\mathrm{gw}}$ is the groundwater runoff (cfs)

This equation was solved using the concentrations for a number of ions and a composite curve was constructed using the mean for several ions. The investigation indicated that in small watersheds in Nova Scotia groundwater discharge represents 32 to 42 per cent of total runoff during flood stage (Fig. 2).

The program of digital modeling and streamflow hydrograph separation involved considerable use of the IBM $360 / 50$ computer at Dalhousie University. 

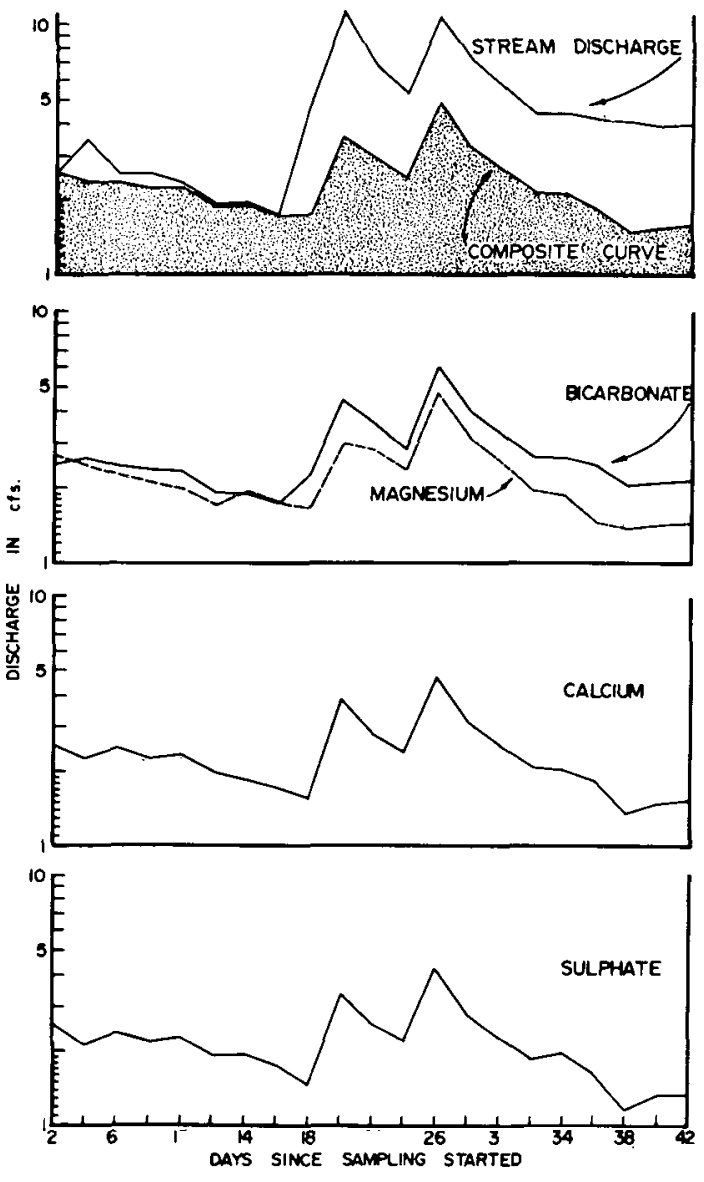

Figu 2 Groundwaer componen of total runoff for April Brook basin calculated using bicarbonate, calcium, magnesium and sulphate ions and a composite curve estimated from these ions.

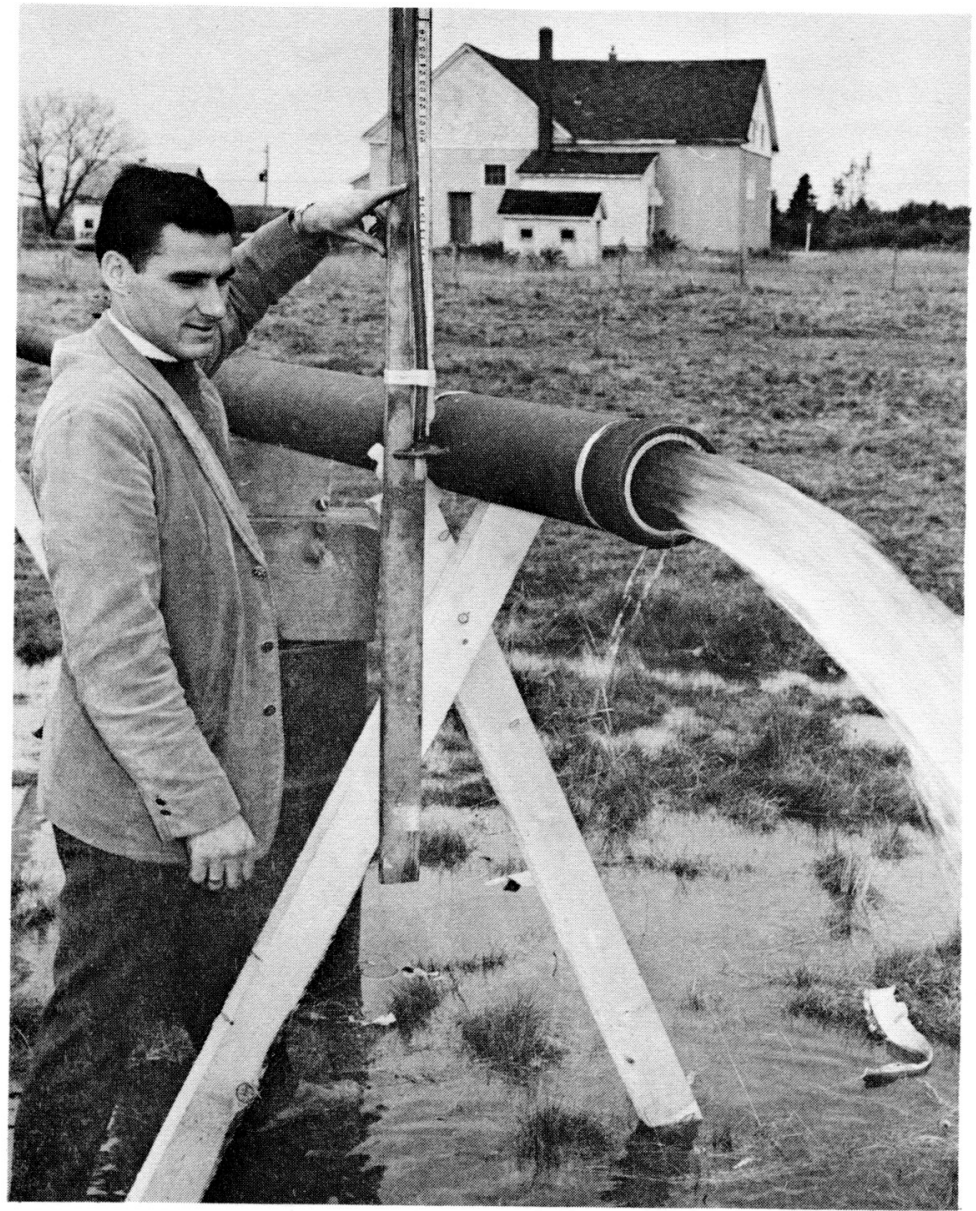

Figure 3 Recent pumping test (rate 430 imp. gallons per minute) of a sand and gravel aquifer near Truro, N.S. Aquifer is capable of producing several million gallons per day. Photo by Nova Scotia Information Branch.

An investigation of the groundwater resources in the Annapolis-Cornwallis Valley has been underway since 1964. This program has been largely under the direction of P. C. Trescott of the Groundwater Section. Trescott has shown that major aquifers are present in the Triassic bedrock and in the overlying surficial deposits. In the extensive Triassic sandstones and conglomerates it is often possible to construct wells which will yield several hundred imperial gallons per minute. Locally in the eastern and central parts of the valley, wells can be constructed in the highly permeable glacio-fluvial aquifers to yield over a thousand imperial gallons per minute. The chemical quality of groundwater from the various geologic units in this area has been determined from hundreds of water samples, and the results have been compared statistically. Piezometer nests have been used to study groundwater movement in one area, and some cases of groundwater pollution were noted. The major part of this investigation has been published (Trescott, 1968); field investigations in the western part of the Annapolis Valley, centered about Digby, and in the Windsor-Walton area east of the Valley are nearly completed. The results of these studies will be published in 1969.

Current investigations include a study of spring discharge records as an index of groundwater discharge in Nova Scotia IHD basins, and study of the chemical quality of groundwater as a reflection of groundwater movement in the Annapolis-Cornwallis Valley.

T. W. Hennigar of the Groundwater Section recently completed his masters thesis (1968) at Dalhousie University, on the hydrogeology of the Salmon River area in the vicinity of Truro. This investigation outlined the grounwater potential mentioned previously (Fig. 3 ).

\section{(3) Basic Data and Other Programs}

Well Inspection and Basic Data:

As a part of its function, the Grounwater Section administers the Well Drilling Act for the 
Province. This Act has requirements for the filing of well logs by contractors (about 1100 water wells are drilled each year in Nova Scotia), well construction, and completion standards and the testing of wells.

Two well inspectors assist with educational programs in co-operation with the well construction industry to upgrade well-drilling techniques and to administer the collection of basic well data.

They also look after an extensive observation well program network established in different aquifers in the province to monitor changes in groundwater levels and flows. This observation well network will enable short and long term fluctuations in groundwater levels to be correlated with climatic changes and water use.

\section{IHD Program:}

As part of Nova Scotia's contribution to the International Hydrological Decade three representative watersheds about 3 to 4 square miles in area have been located in different parts of the province. In these watersheds, instrumentation has been carried out to monitor weather, streamflow, water chemistry, groundwater fluctuations, and other aspects of the hydrologic cycle.

These projects are all co-operative ventures by federal and provincial government agencies, particularly, the Water Survey of Canada, Inland Waters Branch, Canada Department of Energy, Mines, and Resources; the Canada Department of Transport, Meteorological Branch; the Nova Scotia Water Resources Commission; the Nova Scotia Department of Mines; and the Nova Scotia Research Foundation. The Groundwater Section, Nova Scotia Department of Mines is the coordinating agency.

As part of the Canadian IHD program, the third Canadian Hydrology Symposium was held at the Nova Scotia Technical College during the period August 11 - September 7, 1968 . Over 40 engineers, foresters, geologists and meteorologists attended from across Canada. The Groundwater Section in co-operation with the Nova Scotia Technical College assisted in the preparation of the lecture programs and field trips. Lecturers for this course were drawn from the staff of several Canadian Universities and from technical personnel of both provincial and federal agencies.

\section{Conclusions}

During the past year a considerable back-log of basic data was organized and consolidated into a readily usable form. Also the staff has prepared and published several reports pertaining to the subject $r$ eports pertaining to the subject of groundwater. In addition, the results of several research programs have been submitted to outside journals for publication. A partial list of reports and papers, etc. is listed below for the reader's information.

Probably the most exciting development by the groundwater section during the past year, was the project involving the use of the digital computer to solve complex boundary problems of groundwater movement and flow. It is felt that this investigation will provide an effective tool for use in the whole field of groundwater development and management.

Existing programs will continue to be strengthened in depth in order that the groundwater resources of the Province can be evaluated in the best possible manner.

$\underline{\text { Recent Contributions and Reports under Preparation - Staff Groundwater Section }}$

Nova Scotia Department of Mines Published Memoirs, Reports, Etc.

GROUNDWATER SECTION, 1968, Water-well records, Nova Scotia (complete to December 31 , 1965): N.S. Dept. of Mines, Groundwater Section Report 68-1, 145 pp.

, 1968, Before you have a well drilled: N.S. Dept. of Mines, Groundwater Section Report 68-3, 25 pp. (In press) 
Mines, Groundwater Section Report 68-4, 149 pp. (In preparation)

PINDER, G.F., 1968, Hydrogeology of the lower Musquodoboit River valley, Nova Scotia: N. S. Dept. of Mines, Groundwater Section Report 68-2, 21 pp.

TRESCOTT, P.C., 1968, Groundwater resojurces and hydrogeology of the Annapolis-Cornwallis Valley, Nova Scotia: N. S. Dept. of Mines, Mem. 6, 159 pp.

\section{Theses}

HENNIGAR, T.W., 1968, Hydrogeology of the Salmon River and adjacent watersheds, Colchester County, Nova Scotia: Dalhousie University, unpublished M.Sc. thesis, 192 pp.

PINDER, G. F., 1968, A numerical technique for a aquifer evaluation: Univ. of Illinois, unpublished Ph. D. thesis, 73 pp.

TRESCOTT, P.C., 1967, An investigation of the groundwater resources of the AnnapolisCornwallis Valley, Nova Scotia: Univ. of Illinois, unpublished Ph. D. thesis, $269 \mathrm{pp}$.

\section{Outside Contributions}

BREDEHOEFT, J.D. and PINDER, G. F., 1968, A numerical technique for aquifer analysis. (In press)

JONES, J.F., 1967, Groundwater streamflow interactions: Proc. Groundwater Streamflow Systems: Int. Hydr. Decade, Laval University, p. 3-13.

, et al, 1967, Nova Scotia water resources study. Prepared by the Nova Scotia Groundwater Section for the Atlantic Development Board.

PINDER, G.F., 1968, Application of the digital computer for aquifer evaluation: Water Resources Research 4, no. 5, 1069-1093.

, and JONES, J.F., 1968, Determination of the groundwater component of peak discharge from the chemistry of total runoff. (In press)

Open File Reports

HENNIGAR, T. W., 1968, Groundwater Survey, Brookfield Area, Colchester County. , Groundwater Survey, Tatamagouche Area, Colchester County. Groundwater Survey, for Town of Pictou, Pictou County.

Under Preparation

PINDER, G. F. and TRESCOTT, P.C., Piezometers in Nova Scotia: Construction, records, and collection of water samples. (In preparation)

, Optimizing production from an alluvial aquifer in Nova Scotia by use of a digital computer model. (In preparation)

TRESCOTT, P.C., Hydrogeology of the Wolfville (East) - Windsor (Northeast) Area, Nova Scotia: N.S. Dept. of Mines. (In preparation)

- Hydrogeology of the Western Annapolis Valley:N.S. Dept. of Mines. (In preparation) , Groundwater movement in the Annapolis-Cornwallis Valley. (In preparation) and PINDER, G. F., Springs as an index to groundwater discharge in Nova Scotia IHD basins. (In preparation) 